\title{
近赤外線分光法による食品のカロリー測定方法及び測定装置の開発
}

\author{
花松 憲光 ${ }^{1}$, 三浦 克之 ${ }^{1}$, 岡山 透 ${ }^{1}$, 花松 学 $^{2}$, 山端 真弓 $^{2}$ \\ ${ }^{1}$ (地独) 青森県産業技術センター工業総合研究所（ T030-0113 青森県青森市第二問屋町4丁目11-6) \\ ²(株)カロリアジャパン（０34-0001 青森県十和田市大字三本木字北平135-11）

\section{Development of Food Caloric Measurement Method and Instrument by Near-Infrared Spectroscopy}

\author{
Kenkoh HANAMATSU, ${ }^{1}$ Katsuyuki MIURA, ${ }^{1}$ Tooru OKAYAMA, ${ }^{1}$ Manabu HANAMATSU, ${ }^{2}$ \\ and Mayumi YAMAHATA ${ }^{2}$ \\ ${ }^{1}$ Aomori Prefectural Industrial Technology Research Center Industrial Research Institute, 4-11-6 Daini-tonyamachi, Aomori 030-0113 \\ ${ }^{2}$ Caloria Japan Co., Ltd, 135-11 Kitataira, Sanbongi, Towada, Aomori 034-0001
}

(Received November 30, 2010)

\begin{abstract}
We discovered the absorption wavelengths of food calories by near-infrared (NIR) spectroscopy, and developed both a non-destructive measurement method of food calories with these wavelengths and a food caloric measurement instrument based on our developed method. A higher correlation between the referred caloric values and the measured values for the food samples was confirmed using multiple regression equations applied with these wavelengths. We constructed measurement instruments embedded with these multiple regression equations that directly measured food calories. The measurement instrument consists of a NIR source, an AOTF spectroscopy, a detector, a turning table, a controller, and a display. The caloric value of food can be measured by placing the food on the turning table. This food caloric measurement instrument has been commercially available since 2005 .
\end{abstract}

Key Words: NIR spectroscopy, Non-destructive testing, Food, calorie, Chemometrics

1. はじめに

我が国や欧米先進諸国において, 食事のカロリー摂取 過多による肥満と生活習慣病の関係が問題視され, 健康 を維持するためには食事のカロリーコントロールが極め て重要であるといわれている ${ }^{1-4)}$. 本稿は, 一般家庭で も容易にカロリーコントロールを行うことができる装 置, すなわち, 近赤外線分光技術を用いて食品・食材の カロリーを非破壊・非接触で, 簡単に計測する測定装置 を開発し, 実用化, 商品化に至った背景や経緯及び装置 の機構等について概説する.

近赤外線分光法は非破壊的な検査法として, 気象観測 や農産物生育状況等のリモートセンシング技術,56), 及 び農産物等の水分量やタンパク質等の成分分析 ${ }^{7-10)}$ に応 用されている.

食品における熱量は, 食品分析法からの換算法, 燃研 式ボンベ熱量計測法及び日本食品標準成分表を用いた積 算法のいずれかの方法を用いて算出している. 熱量の単 位は, 国際単位系 $(\mathrm{SI})$ はジュール $(\mathrm{J})$ を使用しているが, 生物学, 栄養あるいは食品に関する熱量の単位としてカ
ロリー (kcal) で表記することが認容されている。「五訂

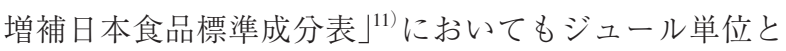
カロリー単位が併記されている。本稿ではあえて食品の 熱量(以下カロリーと表記)を論じるので，単位はkcalを 使用した。

通常, 食品の成分表記には食品分析方法が使用されて いる。 この分析法は公定法として認定されている分析 法 ${ }^{12)}$ であり，糖質， タンパク質及び脂肪の各成分量を測 定し，それぞれのカロリー換算計数を乗じて算出してい る. また, 燃研式ボンべ熱量計測法 ${ }^{13)}$ は被検体の水分量 を蒸散した後, 酸素雲囲気で燃焼させて, 水温上昇值か らカロリーを算出する方法で, 食品や下水污泥等の有機 物の燃焼カロリーを測定するのに適している。しかしな がら, 燃研式ボンベ熱量計測法 ${ }^{13)}$ はヒトが消化できない 繊維成分等もカロリーとして算定するので, 難消化成分 を除去してカロリー換算をする必要がある。「五訂増補 日本食品標準成分表」11) 用いて料理品や調理品のカロ リーを算出する方法は, 食品分析法により代表的な食材 や食品を分析し，その值を蓄積し平均化したもので，食 材や食品の生産地や生産・収穫時期等で成分が変動する 
ため, 正確なカロリー值を算出しているとは限らない. これは，安価であるため利用し易い方法であるが，食 品・食材の計量や積算, 及び摘要食材の選択等の手順の 煩雑さもあって，一般家庭では多少の経験を要するもの である。そのようなことから，日本人の健康志向に対応 して，肥満の要因でもある食事による摂取エネルギーの 管理に必要な料理品又は調理品のカロリーを簡単で瞬時 に，しかも非破壊的に測定できる方法が俟たれている。

非破壊的検査法の一つとして近赤外線分光応用技術に よる方法がある。近赤外線領域を用いた分析技術は1978 年に米国連邦穀物検査局 (FGIS)，及び1982年にはアメ リカ穀物化学者協会 (AACC) 等において近赤外線分光法 が小麦タンパク質の公定分析法として採用され，FGIS においては分析法のマニュアルが作成されているなど広 く知られている ${ }^{14,15)}$ 。また, これまでに農水産物や高分 子化合物の非破壊的検査として近赤外線分光法が数多く 報告 ${ }^{6-9,16-18)}$ され, その応用商品として果物の糖度計や穀 類の食味計などが開発され市販されている。このように 近赤外線応用技術は数多く報告されているにも拘わら ず，食品のカロリーの測定に関する報告は少ない．食肉 について単一食材としてのカロリーを検討した報告 ${ }^{27)}$ は あるが，多様な食品を対象としたカロリー測定方法に， その帰属吸収波長を応用しても殆ど利用できない。すな わち, 近赤外線分光法によって多種多様な食品の力口 リーを直接的に測定するという考えでの研究は殆どおこ なわれていないのが現状である。 また，近赤外線分光法 による方法以外の成分組成による非破壊的なカロリー測 定方法も報告されていない.

このような背景下にあって, 著者らは1998年に「近赤 外線領域において, カロリーに帰属する固有の分子振動 が存在する」という仮説を提唱し, 近赤外線分光法によ る食品のカロリーに関する研究を開始した ${ }^{19)}$. 結果, カ ロリー測定のための帰属波長を見出し, それら帰属波長 による回帰式を組み込んだカロリー測定装置の開発を行 い, カロリー測定装置の試作器を構築した ${ }^{20)}$ 。 その後, 2005年に食品のカロリーを簡易に測定する装置を商品化 した。しかしながら一般家庭への普及には未だ至ってい ない。 その要因として, カロリー測定装置が一般家庭に は高価であることが考えられる。低価格化の妨げになっ ている要素として, ハロゲンランプ光源の使用に伴う, 複雑な光学機構や, 高額な分光機構とその制御が必要で あることが挙げられる.これら照射光源光学機構と分光 機構の 2 つ要素を解決できる方法として任意の波長を発 振できるレーザー光源を利用することが考えられる。 レーザー光源を近赤外線照射光源として利用した，果実 の糖度計 ${ }^{21,22}$ や水分量の測定 ${ }^{23)}$ に関する報告も少なくな い.レーザー技術の応用は食品のカロリー測定方法や装 置のシンプル的な構成に寄与するであろうことは容易に 推測される。

このように食品のカロリー測定方法や装置には多くの 課題があるが, 本稿は今後の発展に資することを期待し て, 近赤外線分光法を応用して食品のカロリーを非破壊 的にしかも簡易に測定する方法とその装置について述べる。

\section{2. 食品のカロリー測定方法とその原理}

食品のカロリー測定は近赤外線分光法を応用し，有機 物 (食品)に照射した光が吸収される現象を利用してい る。近赤外領域の光を食品に照射しその拡散反射光を検 出し, 食品に吸収される波長帯域の光強度を解析するこ とで，食品のカロリーを定量する。

この近赤外線分光法に関する総説や著書は数多くあ $3^{24-26)}$ ，近赤外領域は可視域と赤外域の間にあって，波 長の境界は明瞭ではないが一般に800 nm〜2500 nmの波 長領域の電磁波を近赤外光と呼ぶ. 近赤外域における光 の振動数と物質を構成する分子の振動数が同じとき, 光 が吸収されて分子の振動エネルギーが増加する。近赤外 光の吸収は，分子振動のエネルギー準位を $E_{\mathrm{v}}(\mathrm{v}=0,1$, $2 \cdots)$ とした場合, $E_{0}$ から $E_{1}, E_{0}$ から $E_{2}, E_{0}$ から $E_{3}, E_{0}$ か ら $E_{4}$ へのエネルギー遷移は $\Delta E_{\mathrm{v}}(\mathrm{v}=1 ， 2 ， 3 ， 4)$ と表すこ とができ， $\mathrm{v}=2 ， 3 ， 4$ をるエネルギー遷移が生じる ことで引き起こされる。エネルギー遷移による吸収は, 基準振動の整数倍に相当する波数に現れる(Fig. 1). こ れを倍音による吸収という24-26)

吸収が現れる波数 $v_{\mathrm{n}}$ は，基準振動の波数を $v_{0}$ とする と, $v_{\mathrm{n}}=n v_{0}\{1-(n+1) \chi\}$ と表せる(但し， $n$ は次数， $\chi$ は 非調和定数). $\chi$ は 1 に比べてかなり小さいので, $v_{\mathrm{n}}=n v_{0}$ と近似でき，基準振動の整数倍の波数に吸収が現れるこ とがわかる。また，2個以上の基準振動による吸収が同 時に生じると, 各々の基準振動の波数の和もしくは差の 波数に吸収が現れる。この吸収は結合振動による吸収と いい，吸収が現れる波数を $v_{\mathrm{c}}$ とすると， $v_{\mathrm{c}}$ は， $v_{\mathrm{c}}=n_{1} v_{1} \pm$ $n_{2} v_{2} \pm \cdots$ となる， $n_{1}, n_{2}$ は整数， $v_{1}, v_{2}$ は基準振動の波数 であることから，これらの倍音や結合音の関係から近赤 外域における吸収バンドの化学的な帰属を定義できる. 近赤外域の光の吸収はすべて赤外域における基準振動の 倍音 (over-tone) または結合音 (combination)による分子振 動によって生じ，主に水素原子が関与する $\mathrm{O}-\mathrm{H}, \mathrm{N}-\mathrm{H}$, $\mathrm{C}-\mathrm{H}$ の官能基による ${ }^{25)}$

このような光の吸収作用を利用し，標準サンプルにお ける透過もしくは反射光強度と, 試供サンプルにおける 透過もしくは反射光強度を比較することで, 吸光度が計 算できる，吸光度は波長ごとに計算し，吸光度スペクト ルすなわち近赤外スペクトルを得る。試供サンプルの近 赤外スペクトルにおける吸収バンドは，構成する成分特 有の官能基に基づくものであるが，構成成分の含量によ り吸収バンドは変化する。近赤外線分光法は, 複数の情 報が含まれる近赤外スペクトルから，重回帰分析などの

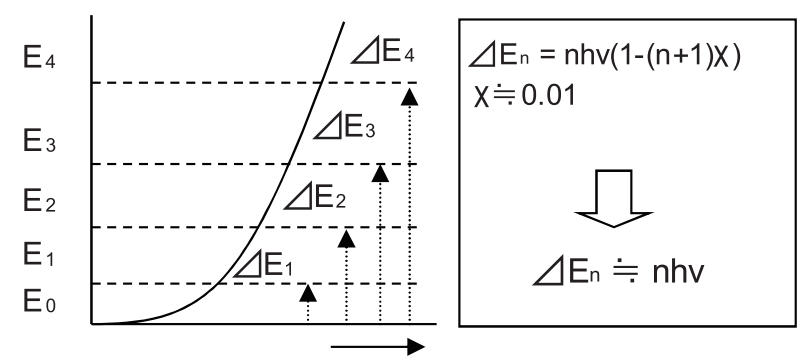

Fig. 1 Energy level and transition energy. 
統計的手法を用いて, 近赤外スペクトルデータと食品分 析法などの従来法によって得られた分析值から検量線を 構築し，未知サンプルの構成成分の含量を予測する手法 である。近赤外線分光法の特徵は, 従来法に比べ簡易迅 速な測定が可能で，更に，従来法では試料形態に制約が あることや，単一成分を測定するものが大部分である。

一方，近赤外線分光法は殆どの試料形態に適応でき色々 な成分の測定が可能となる，従って，簡便性や迅速性及 び非破壊性において従来法と比較して優位である.

食品のカロリー測定方法と装置は, この手法によりカ ロリーにおける検量線 $\left(Y=K_{0}+K_{1} A\left(\lambda_{1}\right)+K_{2} A\left(\lambda_{2}\right)+\right.$ $K_{3} A\left(\lambda_{3}\right)+K_{4} A\left(\lambda_{4}\right)$, 但し, $Y$ は予測值, $K_{0} \sim K_{4}$ は定数, $A$ $\left(\lambda_{1} \sim \lambda_{4}\right)$ は選択波長1〜4における吸光度)を構築し，己 れを用いてカロリーを算出及び表示するものである.

具体的には, 光源にハロゲンランプを使用し, 近赤外 域1100 nm〜2200 nmの範囲を2 nmステップで分光し, 分光した光を食品に照射し, 食品からの拡散反射光を複 数の光検出器で検出する. 検出した光強度信号をノイズ 処理等の信号処理を行い, 食品の近赤外スペクトルを算 出する，その食品の近赤外スペクトルを検量線に当ては めることで, 従来法のようにタンパク質, 脂質, 炭水化 物といったエネルギー源を特定・定量することなく, 直 接的に食品のエネルギーを簡便に迅速に測定することが できる装置である。

\section{3. 食品のカロリーと近赤外線吸収波長}

食品のカロリー測定法と装置に関する特徵は, 食品で ある物体のカロリーに帰属する近赤外線の波長域を見出 し，その波長域を用いて，直接的にカロリーを測定する 点である. 一般的に, 近赤外線分光法による非破壊的検 查方法は目的とする物体又は物質の吸収波長を用いた方 法で行っている，食品のカロリー測定法においても，そ の帰属する吸収波長を決定する必要がある。

カロリーの帰属波長は重回帰分析法によって探索し た. 予めカロリー值が既知の多くの試料と, 近赤外線分 光法による吸収波長との重回帰分析によって, 相関係数 が最も高い波長を第 1 波長とし，相関係数が 0.800 以上を 示す波長で決定している. カロリーの誤差範囲を広く設 定することで, 十分に第1波長だけで測定することも可 能である。しかしながら，カロリーの測定精度をより高 めるには高次の回帰式が必要である。第2波長〜第 $n$ 波長 の決定は, 多重共線性を示さない波長域であり, 重回帰 分析により相関係数と標準誤差の值を以って行われる. 一般式として, 各波長の吸光度を変数とする下記の関係 を満たす式で構成される。

$$
\begin{array}{r}
C=K_{0}+K_{1} \frac{d^{2} A\left(\lambda_{1}\right)}{d \lambda^{2}}+K_{2} \frac{d^{2} A\left(\lambda_{2}\right)}{d \lambda^{2}}+K_{3} \frac{d^{2} A\left(\lambda_{3}\right)}{d \lambda^{2}}+\ldots \\
\ldots+K_{\mathrm{n}} \frac{d^{2} A\left(\lambda_{\mathrm{n}}\right)}{d \lambda^{2}}
\end{array}
$$

一般式(1)において, Cはカロリー (kcal/100g)入は波
長, $\mathrm{A}\left(\lambda_{1}\right)$ は第1波長 $\left(\lambda_{1}\right)$ の吸光度, $\mathrm{A}\left(\lambda_{2}\right)$ は第2波長 $\left(\lambda_{2}\right)$ の吸光度, $\mathrm{A}\left(\lambda_{3}\right)$ は第3波長 $\left(\lambda_{3}\right)$ の吸光度, $\mathrm{A}\left(\lambda_{\mathrm{n}}\right)$ は第 $n$ 波 長 $\left(\lambda_{\mathrm{n}}\right)$ の吸光度, $K_{0}, K_{1}, K_{2}, K_{3}, \ldots, K_{\mathrm{n}}$ は, 充分に多い 母集団において測定された吸光度及び食品分析によるカ ロリー值を用いて最小二乗法で決定された係数である.

具体的には, 食品のカロリーに帰属波長の探索は近赤 外線分光分析装置(MODEL 6250：ニレコ社，東京)を用 いて, 波長範囲1100 nm 2500 nm, 波長分解能 $2 \mathrm{~nm}$, 積算回数100回の反射方式による方法で供試材料の吸光 度を測定して行った。供試材料として市販の菓子類，野 菜類, 乳肉類, 及び魚類等294検体を用いた。 これらの カロリー值はタンパク質量, 脂質量及び糖質量の各成分 を公定法 ${ }^{12)}$ で定量し，エネルギー換算係数を乗じた值を 用いた。それら供試材料を近赤外線分光装置で測定した 吸光度データを二次微分処理して説明変数とし, 食品分 析によるカロリー值を目的変数として逐次変数選択重回 帰分析 (変数増加法) 法で解析した.

第1波長 $\left(\lambda_{1}\right)$ は，成分分析による既知のカロリー值と その近赤外線吸光度 (二次微分) の相関係数が -0.800 以 下となる波長域を選択した(Fig. 2)。これら第1波長 $(\lambda 1)$ と, 第 2 波長 $\left(\lambda_{2}\right)$ 第 $n$ 波長まで, 重相関係数, 決定係数 及び標準誤差の結果からカロリー測定に最適な波長を選 択した。因みに，供試材料256検体について，4波長 （1146 nm，1726 nm，1896 nm，2306 nm）を選定した場

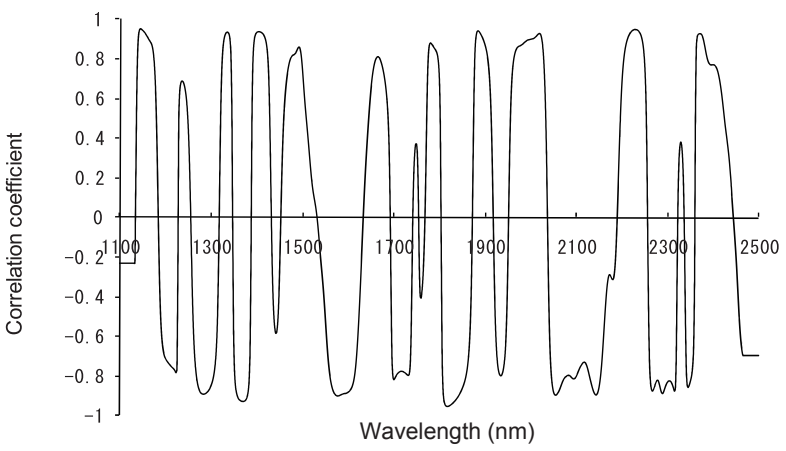

Fig. 2 Correlation coefficient between the degree of light absorption for the first wavelength and the caloric value.

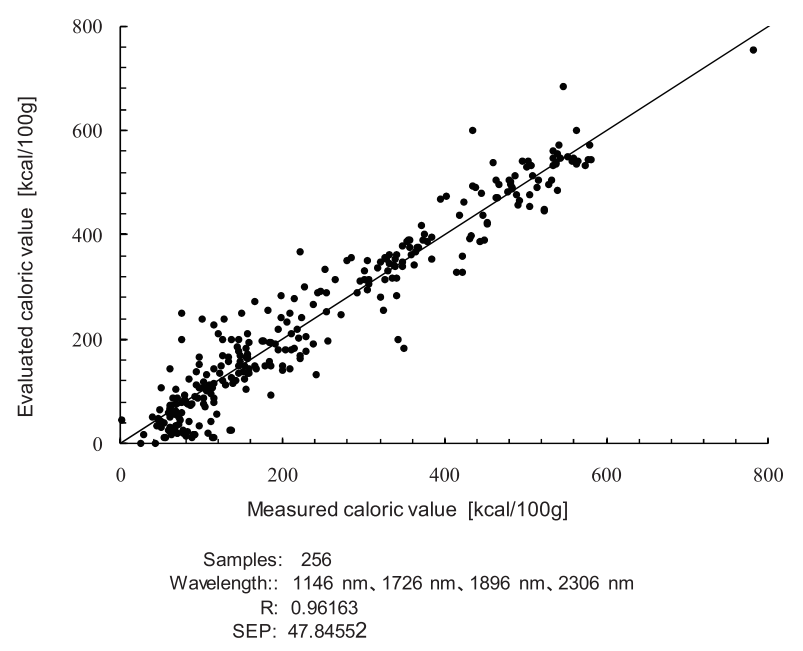

Fig. 3 Correlation of the caloric values between the evaluation based on the food analytic method and the measurement with NIR spectroscopy. 
合, 既知の成分分析によるカロリー值との関係は, 重相 関係数が 0.96163 , 重決定係数が0.924733, 標準誤差が 47.84552 となり, 極めて高い相関が認められた(Fig. 3).

\section{4. カロリー測定装置の構成}

食品のカロリーを測定する帰属吸収波長が近赤外線領 域に存在すること, 及びその回帰式が極めて高い相関が 認められたことから，この近赤外線分光法を応用し，食 品のカロリーを測定する装置の開発を試みた。 その装置 構成などを紹介する。

\section{1 装置構成}

本装置は光源部(1), AOTF分光部(2), 検出部(3), テーブル部(4), 制御部 (5), 及び表示部(6)で構成した (Fig. 4).

光源部 (1) は白色光源 (ハロゲンランプ12 V-1.67 A) を 用い, 出力した光をスリット及び複数の光学レンズで光 束調整し, 低波長域を光学フィルタでカットした。 AOTF分光部 (2) は音響光学素子 (Acousto-Optic Tunable Filter: AOTF, TEAF5-1.1-2.2H: Brimrose社製, 米国)を用 いて，波長1100 nm〜2000 nmの範囲について，2 nm間 隔で分光した，すなわち，この光源部及び分光部の構成 は，ハロゲンランプの光をコンデンサレンズで構成した 照明光学系により集光し, ピンホールにより絞られた光 束をフォーカスレンズで構成された結像光学系でAOTF 結晶中に結像させる光学系である (Fig. 5). その際にロ ングパスフィルタを透過させることで, 分析に必要な $1100 \mathrm{~nm}$ 以上の光を抽出し, AOTFへの入射角度は光学 系光軸に対して $6^{\circ}$ 以内とする. AOTFを駆動すること で, 0 次光に対して \pm 1 次光が得られ, 駆動周波数 (同調 周波数)を可変することで白色光源から任意の波長の近 赤外光のみが得られる。 そのAOTFの光学特性の評価

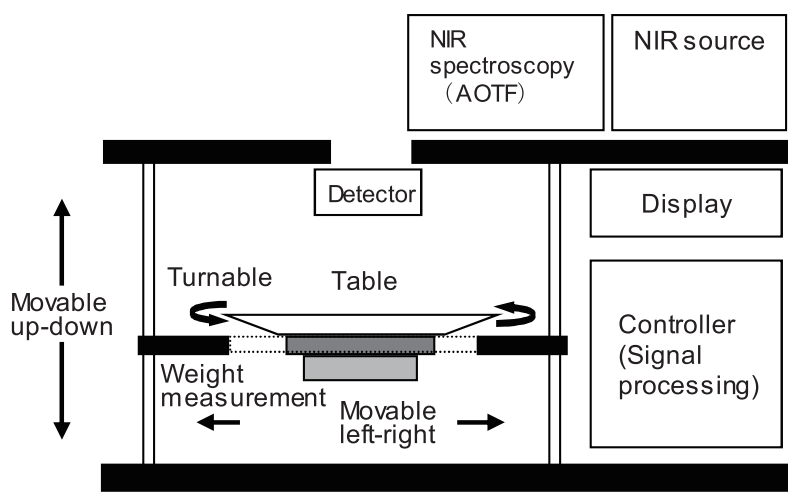

Fig. 4 Schematics of prototype machine.

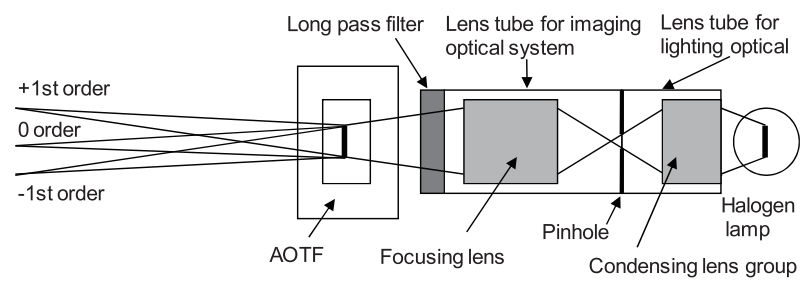

Fig. 5 Principles of the spectroscopy system in the caloric measurement instrument.
は，IRレーザー光源を用いて，集光レンズ，絞り， AOTF，IRプレート(蛍光板)で構成したシステム系で 行った(Fig. 6)．IRプレートにブラックライトを照射す ることで赤外線が照射された場所が暗くなり黒点として 可視化できる(Fig. 7)。構築したAOTFによる波長 $1100 \mathrm{~nm}$ の分光スペクトル例を示した (Fig. 8).

検出部(3) は分光された光を食品サンプルに照射し, その食品サンプルからの拡散反射光を近赤外線検出器で ある $\mathrm{PbS}$ センサで検出した。テーブル部(4)は食品サン プルを載せるテーブルで, テーブルは3つの駆動モー ターで食品サンプルの高さに合わせ照射，検出距離を一 定に保つ上下移動, 及び広範囲の測定のため水平移動と 回転動作ができる機構とした。また，食品サンプルの重 量測定機能(歪ゲージ)を備える。制御部 (5)は信号処理 機能や吸光度の算出に必要な波形処理, 及びカロリー演 算機能や重量測定值から総カロリーを演算する演算処理 機能，並びに分光波長の指定や各モーターの制御，光源 の出力及び停止や様々なスイッチの状態を把握する入出

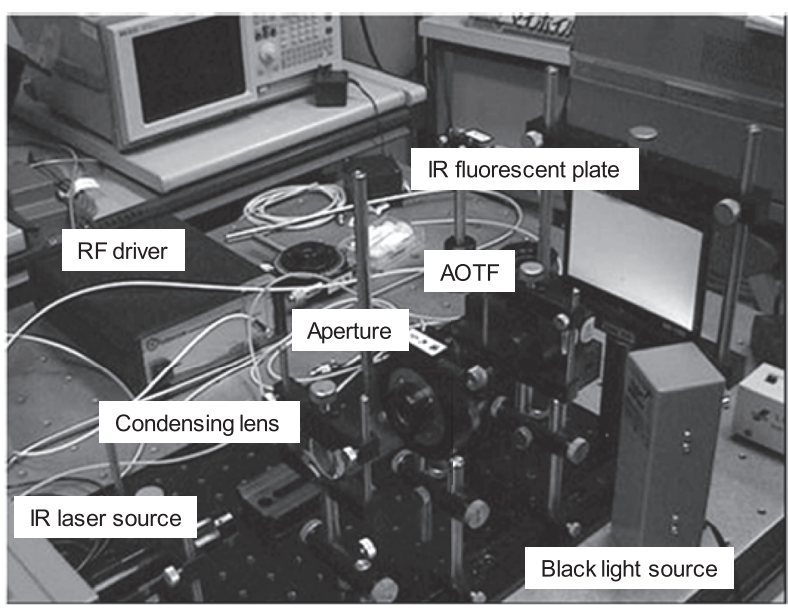

Fig. 6 Optical characteristic testing system for AOTF.
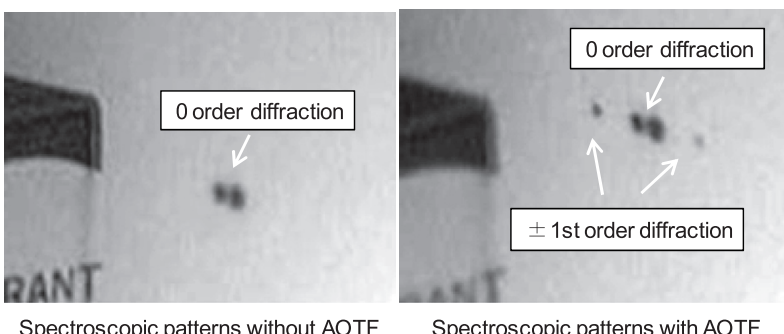

Fig. 7 Spectroscopic patterns by AOTF.

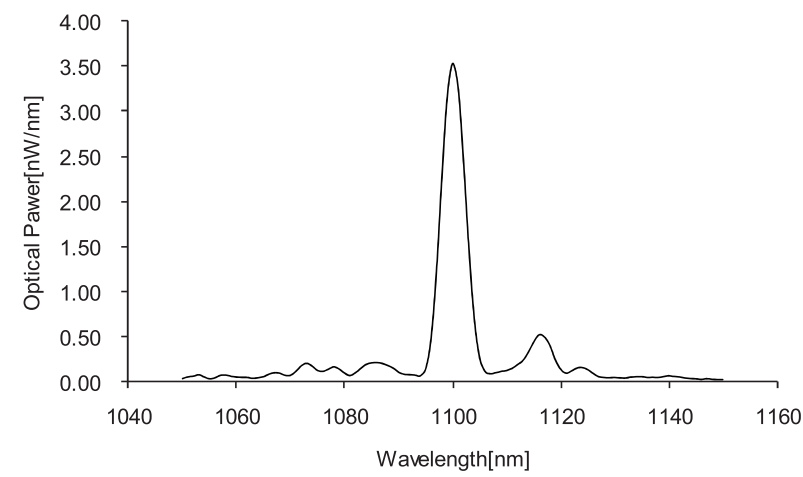

Fig. 8 Spectroscopic spectrum around the wavelength of $1100 \mathrm{~nm}$ by using AOTF. 
力制御機能等を備える。これらのプログラムはグラフィ カル言語LabVIEW (National Instruments社製)で構築し, カロリー測定装置の統合制御を行った。表示部(6)は TFTカラー液晶タッチパネルに食品の重さやカロリー測 定值等の結果を表示した。試作装置の内部の写真を Fig. 9に示す.

\section{2 測定フロー}

測定は, 予め容器を本装置で重量測定し風袋ゼロ設定 を行った後, その容器に食品を盛付けて, 測定を開始す る。食品上端面が所定の高さになるまでテーブルが上昇 する，近赤外線を食品に照射し，近赤外スペクトルを得 る。なお，テーブルの水平移動及び回転を適宜行うこと で食品全体を測定する。食品全体の測定完了後, テーブ ルを初期位置に戻し, 全測定箇所での平均と食品の重量 から食品全体の総カロリーを計算し表示する.

\section{3 試作機における食品のカロリー測定成績}

本試作機を用いて, 食品30検体のカロリーを7波長 $(1704 \mathrm{~nm}, 1400 \mathrm{~nm}, 1738 \mathrm{~nm}, 1196 \mathrm{~nm}, 1260 \mathrm{~nm}$, $1590 \mathrm{~nm}, 1348 \mathrm{~nm}$ )の重回帰式で測定した場合の成績を Table 1及びFig. 10に示した。試作機によるカロリー測定 值と既知カロリー值 (五訂増補日本食品標準成分表に よって算出) との相関係数は 0.986 , 標準誤差は32.923で あった。よってカロリーの測定が十分可能である成績を 得た。また，1つの検量線で0〜 $1000 \mathrm{kcal} / 100 \mathrm{~g}$ までの低 カロリー領域から高カロリー領域までの広範囲な測定が できた。コンニャクなど食物繊維は， C, H, Oの元素 で組成されているが，ヒトではエネルギー源として直接 的に利用できないため, 日本食品標準成分表では, 極め て低いカロリー值 $(0 \sim 4 \mathrm{kcal} / 100 \mathrm{~g})$ で表している. 本試 作機の測定においても, 食物繊維やコンニャクは極めて 低いカロリー值を示している。

本試作機は，ヒトがエネルギー源として利用できる物 質量を測定しているものと考える。これは燃研式ボンベ 熱量計で測定するC，H， Oの燃焼に起因する有機物全 体の物質量のカロリー值とは異なるものであって, ヒト が利用できるエネルギー源のみを測定できることを特徵

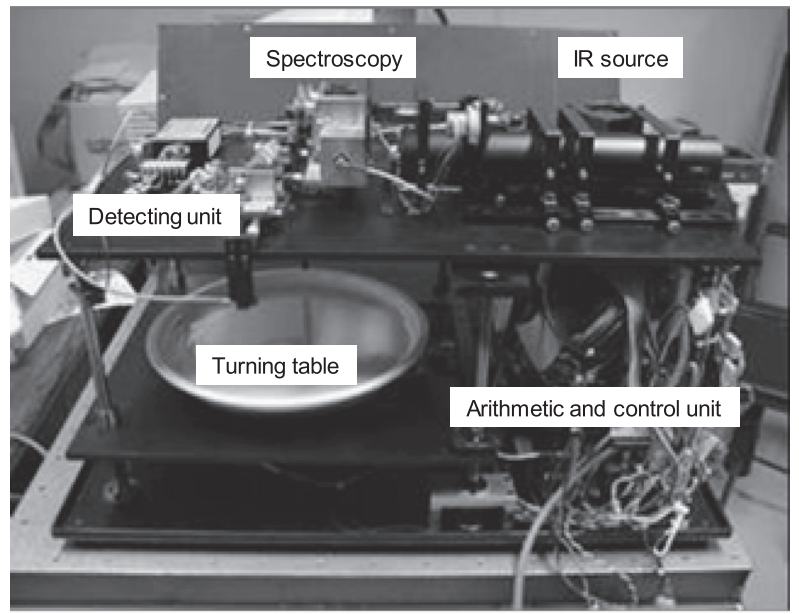

Fig. 9 Anatomy of the caloric measurement.
Table 1 Comparison of caloric values for some foods between the referrence from the strandard table and the measurement with the prototype machine.

\begin{tabular}{|c|c|c|}
\hline Food Sample & $\begin{array}{c}\text { Referred caloric value } \\
{[\mathrm{kcal} / 100 \mathrm{~g}]}\end{array}$ & $\begin{array}{c}\text { Measured caloric value }{ }^{* *} \\
{[\mathrm{kcal} / 100 \mathrm{~g}]}\end{array}$ \\
\hline Cellulose & 0.0 & 0.0 \\
\hline Konjac & 2.0 & 0.0 \\
\hline Chinese cabbage & 14.0 & 31.2 \\
\hline Japanese radish & 18.0 & 29.7 \\
\hline Tomato & 19.0 & 24.3 \\
\hline Spinach & 20.0 & 59.3 \\
\hline Broccoli & 32.0 & 24.7 \\
\hline Asparagus & 35.0 & 23.1 \\
\hline Carrot & 37.0 & 47.1 \\
\hline Jelly & 46.1 & 12.8 \\
\hline Pear & 54.0 & 92.1 \\
\hline Sprout of garlic & 59.0 & 27.8 \\
\hline $\begin{array}{l}\text { Rice cooked with } \\
\text { konjac }(5: 5)\end{array}$ & 72.0 & 63.7 \\
\hline Com & 97.0 & 112.6 \\
\hline Hanpen & 101.6 & 92.7 \\
\hline Green beans & 110.0 & 83.6 \\
\hline $\begin{array}{c}\text { Rice part } \\
\text { (pork cutlet on rice) }\end{array}$ & 120.0 & 117.8 \\
\hline Baked chikuwa & 123.3 & 64.9 \\
\hline Edamame & 139.0 & 140.3 \\
\hline A bowl of rice & 144.0 & 102.7 \\
\hline $\begin{array}{c}\text { Filling part } \\
\text { (pork cutlet on rice) }\end{array}$ & 153.0 & 151.2 \\
\hline Box lunch 1 & 179.0 & 173.8 \\
\hline Box lunch 2 & 205.0 & 189.6 \\
\hline Box lunch 3 & 208.0 & 174.8 \\
\hline Sausage & 282.0 & 268.2 \\
\hline Wiener & 291.0 & 283.1 \\
\hline Cheese & 335.0 & 367.4 \\
\hline Salami & 385.0 & 382.6 \\
\hline Snack & 560.0 & 511.0 \\
\hline Lard & 941.0 & 1130.2 \\
\hline
\end{tabular}

*STANDARD TABLES OF FOOD COMPOSITION IN JAPAN Fifth Revised.

** Caloric measurement prototype machine.

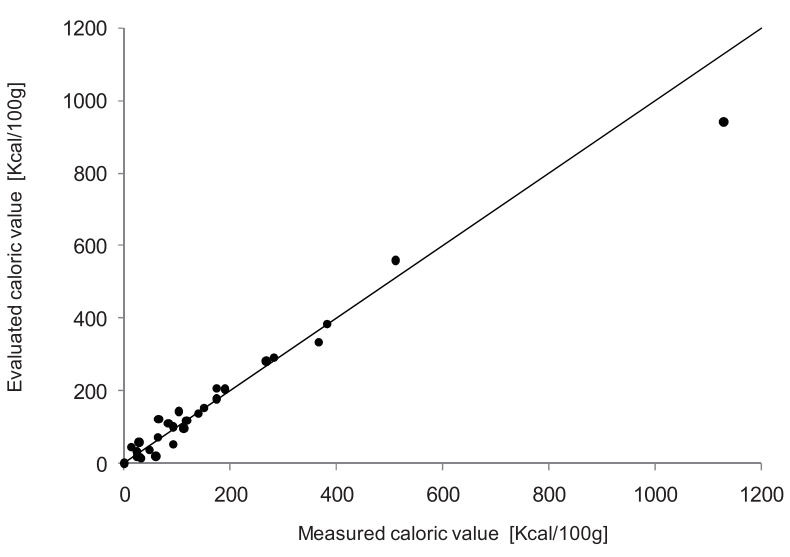

Wavelength : $1196 \mathrm{~nm}, 1260 \mathrm{~nm}, 1348 \mathrm{~nm}, 1400 \mathrm{~nm}, 1590 \mathrm{~nm}, 1704 \mathrm{~nm}, 1738 \mathrm{~nm}$ samples: 30 R: 0.986 SEP : 32.923

Fig. 10 Correlation of the caloric values between the evaluation based standard tables of food composition in Japan and the measurement with the prototype machine.

としている 


\section{5. 食品の形態や種類とカロリー測定}

一般的に, 近赤外線分光法は水分による影響は大きい と言われている。被検体の水分量がカロリー測定に及ぼ す影響について, 即席麺に熱水を加えて, 直後, 10分 後, 15分後, 20分後のカロリー值を検討した，その結 果，直後は測定誤差が大きくなる傾向を示した (Table 2)。本装置に扔けるカロリー測定は, 被検体の含 水率よりも，表面に水分が存在する状態で測定に与える 影響が大きいと考える。実際のカロリー測定には，例え ば,「スープ」や「ラーメン」等の水分が食品表面まで存在 する場合，測定法について注意を要する。

\section{6. 応用製品}

近赤外線分光法を応用した食品のカロリーを測定する 方法とその試作に関する研究開発の結果, 十分に実用化 が可能である成績が認められた。 そこで，これらの基礎 的な技術に基づいて, カロリーの測定可能範囲を広域化 し, 水分状態の影響を除去する改良を行うことで測定性 能の向上を図った。また, 商品化に関して, 装置の安定 性や耐久性, 及び筐体のデザイン等の技術的な検討を行 い, 2005年に食品のカロリー測定装置(商品名：カロ リーアンサー $\left.{ }^{\circledR}\right)$ が市販されだ。

この装置は洋菓子や和菓子類，野菜，魚肉類，それら

Table 2 Effect of the amount of moisture on the caloric values.

\begin{tabular}{cccc}
\hline $\begin{array}{c}\text { Time after adding } \\
\text { moisture [min] }\end{array}$ & Weight $[\mathrm{g}]$ & \multicolumn{2}{c}{ Caloric values [Kcal/100 g] } \\
\cline { 3 - 4 } & & Evaluated $^{*}$ & Measured $^{* *}$ \\
\hline soon after & 482 & 92 & 138.5 \\
10 & 421 & 105.2 & 128.5 \\
15 & 350 & 125.8 & 138.3 \\
20 & 300.6 & 147.2 & 146.8 \\
\hline
\end{tabular}

*Evaluated by the food analysis method.

** Measured with the prototype instrument.

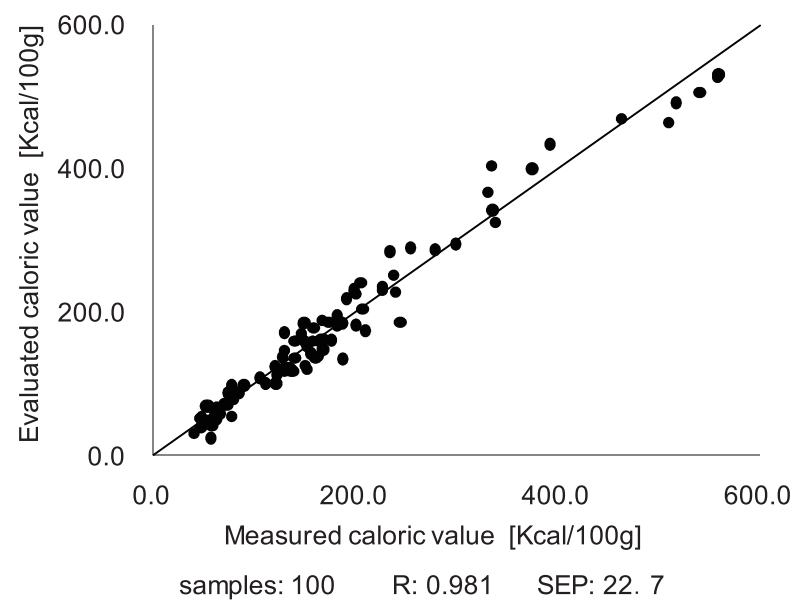

Fig. 11 Correlation of the caloric values between the evaluation based on the food analytic method and the measurement with Calory Answer ${ }^{\circledR}{ }^{\dagger}$
の混合調理品等の固形食品系用として開発された商品で ある。洋菓子や和菓子類, 野菜, 魚肉類, 及び混合調理 品等のカロリーを測定した結果, 成分分析による換算力 ロリー計算値とは極めて高い相関を示している (Fig. 11)

次に，測定精度は，健康増進法で定められている栄養 表示基準では基準值との誤差率 $\pm 20 \%$ 以内と規定して いる ${ }^{28)}$ ，食品メーカによっては産地や季節品による成分 誤差があるという見解から，「糖質 $0 \sim 10 \mathrm{~g} 」$ と，幅を持 たせて表示している例もあり，誤差率士20\%という值 はあくまでも基準值として考え，評価の際は上記の值を 参考として活用されたい。高田ら ${ }^{29)}$ は固形食品への応用 では満足するカロリー值を示し，液体系食品には誤差が 大きいことを述べている，水分に浸漬しているような液 体系食品類においても計測できる装置構成やソフトウエ アの開発が必要である。

\section{7. 今後の展開}

本稿では近赤外線分光法によって，食品のカロリーに 帰属する波長を統計学的な手法で探求し, その帰属波長 を用いた重回帰分析法でカロリーを測定することを明ら かにした。特に，カロリー測定装置は有機物の組成分で あるC， H， Oの燃焼に起因する単なる成分量のカロ リーとは異なるものであって，ヒトが利用できるエネル ギー源となる成分量を測定することによって，カロリー を計測することに意義があることを力説しておきたい. しかしながら, 食品のカロリーが近赤外領域で直接的に 測定できることに関する理論的な解明がなされていな い. 最近, 近赤外線とカロリーについて数例の報告 ${ }^{15-17)}$ があるけれども，理論的に解明しようとするアプローチ がなく, 分析化学やケモメトリックス, 近赤外線分光法 等を駆使して, 分子運動力学的な分野から研究が進展す ることで，食品のカロリーについても新たな発見が期待 できるものと考える.

次に，食品のカロリー測定装置に関して，本稿では近 赤外線光源としてハロゲンランプを用いてAOTFによる 前分光法で実施しているが, 後分光法でも構築可能であ る. 分光方式によって光源が選択され, 装置の性能や簡 素化及び低価格化等に極めて大きな影響を与える。目的 に応じた装置の設計概念が重要である。

今回はハロゲン光源を用いてAOTFで分光を行ってい るが，その他の分光方式であってもカロリー帰属波長を 応用すればカロリー測定が可能である，装置の低価格化 のためには, 複雑な光学構成や高価な分光装置を必要と しない方法を採用することは当然のことであって，一つ の手法としてレーザー技術の応用が考えられる，複数の レーザーダイオードを用いて非破壊果実糖度計が開発さ れている報告 ${ }^{21} や ，$ 半導体レーザーを用いた水分ストレ スの計測法等 ${ }^{30}$ を応用した例もあり，近い将来において 半導体レーザー等を用いた低価格で小型軽量な食品のカ

†「カロリーアンサー」は(株)ジョイワールドパシフィックの登録商標である. 
ロリー測定装置が開発されるであろう。またレーザー 光を利用したテラヘルツ分光技術 ${ }^{31)}$ を応用すれば， 新た な食品のカロリーを測定する方法も提唱されると考え る. 今後, 食品のカロリー測定に対するレーザー応用技 術分野からの研究開発を大いに期待するものである.

近赤外線分光法により, 従来の化学 ·物理的手段を組 合せた抽出技術や化学反応を用いた分析技術を応用する 方法, すなわち, 滴定や試薬の調整等の煩雑で複雑な専 門技術や操作等が不要になり，簡易に迅速且つ高精度に 食品のカロリーの直接的な測定が可能となった。 そのた め, 一般家庭において食品のカロリーを簡易に測定する ことで，健康維持管理に貢献できるものと考える.

\section{8. まとめ}

近赤外領域における食品のカロリー帰属吸収波長を発 見し, カロリー測定方法と装置を開発した。 その結果に 基づいて，一般家庭においても食品のカロリーが非破壊 的に測定できる技術を紹介した。

\section{参考文献}

1) 森井 浩世：大塚薬報 498 (1995) 42.

2) 岡山明：血圧 5 (1998) 1189

3) CMPジャパン株式会社 : 食品と開発 42 (2007) 37 .

4）稲岡説二郎：Monthlyフードリサーチ 663 (2010) 59.

5) B. F. T. Rudorff and G. T. Batista: Remote Sensing Environ 31 (1990) 53.

6）小松田忠良, 青柳 賢英, 佐鳥 新, 竹内 佑介：北海道工業 大学研究紀要 38 (2010) 123.

7）伊予知枝：ぶんせき 8 (2002) 450 .

8）川村 周三 : 食品工業 51 (2008) 60 .

9) T. Sato, K. Eguchi, T. Hatano, and Y. Nishiba: Plant Prod. Sci. 11
(2008) 481.

10) E. Zamora-Rojas, A. Garrido-Varo, J. E. Guerrero-Ginel, D. C. Perez-Marin, and F. Van Den Berg: Chemometr Intell. Lab. Sys. $101(2010) 87$.

11）日本国 文部科学省科学技術・学術審議会・資源調査分科 会：(2005) 9.

12）(社）日本食品科学工学会，新・食品分析法編集委員会編： 新・食品分析法 (光琳, 東京, 1996).

13）西宮伸幸：化学と教育 $\mathbf{5 8}$ (2010) 32

14）尾崎 幸洋，河田 聡 編：近赤外分光法 (1996) 5 .

15) USDA-FGIS, ED.: Grain Inspection Hand-book V. Wheat Protein (USDA, Washington, D. C., 1987).

16) S. G. Bajwa, J. Kandaswamy, and J. K. Apple: J. Food Eng. 92 (2009) 454.

17) D. Gillon, R. Joffre, C. Hernando, and J.-C. Valette: Can. J. For Res. 27 (1997) 760.

18）井上 隆一郎：青森公立大学経営経済学研究 15 (2010) 19.

19）地方独立行政法人 青森県産業技術センター工業総合研究 所：キープロジェクト研究報告書 5 (2001) 233.

20）花松 憲光，小野浩之，小田桐 英夫，沢隆裕，三浦克之： JP Patent 4104075 (2008)

21）鈴木 光：光アライアンス 14 (2003) 19

22）下村 義昭：長崎県工業技術センター研究報告 32 (2004） 1 .

23）福田光男, 松尾あかね, 神野弘明, FARZANA Islam, 中山 尚之, 大山祥吾, 内海 淳志, 田辺 隆也：植物環境工 学 21 (2009) 7.

24）尾崎 幸洋，河田 聡編：近赤外分光法（1996） 16 。

25) (社) 日本食品科学工学会: 非破壊計測シンポジウム講演要 旨集 14 (1998) p.1.

26) 河野 澄夫：応用物理 70 (2001) 660 .

27) M. Mitsumoto, T. Mitsuhashi, S. Ozawa, and S. Maeda: J. Food Sci. 56 (1991) 1493

28）日本国 厚生労働省：健康増進法第31条第1項（1998）。

29）高田和子, 別所京子, 三浦克之, 沢隆裕, 小田桐英夫： 日本栄養・食糧学会誌 62 (2009) 75.

30）兵頭 竜二, 下村 義昭, 高見 寿隆, 一丸禎樹, 松尾畫一： 長崎県工業技術センター研究報告 32 (2004) 17 .

31) C. Jansen, S. Wietzke, O. Peters, M. Scheller, N. Vieweg, M. Salhi, N. Krumbholz, C. Joerdens, T. Hochrein, and M. Koch Appl. Opt. 49 (2010) E48.
食物のカロリー計測 (measurement of food calories)

ヒトや動物の体内でエネルギー源として利用できる食 物の含有成分量の測定. 物質の燃焼に寄与する単なるエ ネルギー源の総量でなく, ヒトの場合は三大栄養素であ る糖質, 脂肪及びたんぱく質を栄養分析法によって定量 して，各エネルギー係数を乗じて算定する。エネルギー

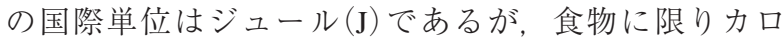
リー(kcal) が認められている。一般的な栄養指標とし て, 食物のカロリーを得る場合には「日本食品標準成分
表」を用いて算定. 食品分析法は専門技術と日数を要し 簡易的になく，成分表は食物の生産地や収穫時期等の変 動要因等があって，その食物の正確なカロリーを算出し ているとは限らない．近赤外線分光法によるカロリー計 測は，その食物の三大栄養成分量を計測してカロリー換 算する方法や直接的にカロリーに帰属する波長を用いる 方法があって，非破壊的で簡易に測定することができ る.

(花松 憲光) 